\title{
Sewage sludge as barrier material for heavy metals in waste landfill
}

\author{
Huyuan Zhang*, Bo Yang, Guangwei Zhang, Xuechao Zhang \\ Key Laboratory of Mechanics on Disaster and Environment in Western China (Lanzhou University), \\ Ministry of Education, China
}

*Corresponding author's e-mail: zhanghuyuan@|zu.edu.cn

Keywords: sewage sludge, hydraulic conductivity, heavy metal pollution, heavy metal retardation.

\begin{abstract}
Heavy metal pollutants in the leachate of waste landfill are a potential threat to the environment. In this study, the feasibility of using municipal sewage sludge as barrier material for the containment of heavy metal pollutants from solid waste landfills was evaluated by compaction test and hydraulic conductivity test concerning compaction property, impermeability and heavy metal retardation. Results of the compaction test showed that the maximum dry density of $0.79 \mathrm{~g} \cdot \mathrm{cm}^{-3}$ was achieved at the optimum water content of about $60 \%$. The hydraulic conductivities of compacted sewage sludge permeated with synthetic heavy metal solutions were in the range of $1.3 \times 10^{-8}-6.2 \times 10^{-9} \mathrm{~cm} \cdot \mathrm{s}^{-1}$, less than $1.0 \times 10^{-7} \mathrm{~cm} \cdot \mathrm{s}^{-1}$ recommended by regulations for barrier materials. Chemical analyses on the effluent from the hydraulic conductivity tests indicated that the two target heavy metals, $\mathrm{Zn}$ and $\mathrm{Cd}$ in the permeants were all retarded by compacted sewage sludge, which might be attributed to the precipitation and adsorption of heavy metal ions. The results of this study suggest that specially prepared material from sewage sludge could be used as a barrier for waste landfills for its low permeability and strong retardation to heavy metal pollutants.
\end{abstract}

\section{Introduction}

Heavy metal pollutants, widely distributed in the solid waste, such as waste rock, tailing and municipal solid waste incineration ash, might be leached out by the water originated from the infiltration of rainfall or groundwater and then dissolved into the leachate (Jung et al. 2004, Lottermoser 2010). Uncontrolled discharge of the leachate with evaluated heavy metal pollutants into the surrounding area may lead to the pollution of surface waters and groundwaters, and in consequence the soils and sediments (Ciesielczuk et al. 2014, Jonczak and Parzych 2014, Lemanowicz and Bartkowiak 2013, Lottermoser 2010). These heavy metals in the polluted area are taken up and then accumulate in plants, animals and humans (Duruibe et al. 2007). Heavy metals have been known to cause severe impacts on environment and human health and have received increasingly concern around the world in the past decades (Baun and Christensen 2004, Duruibe et al. 2007, Järup 2003).

An effective and conventional strategy to control or minimize the effects of leachate is containing solid waste by single or composite barrier. Owing to its low permeability, compacted clay liner (CCL) has been widely used as barrier to mitigate the migration of the pollutants for decades (Manassero et al. 2000). Currently, geosynthetic clay liner (GCL) and geomembrane (GM) have also been used in landfill sites to prevent leachate from contaminating groundwater due to their low hydraulic conductivity and relative ease of installation
(Manassero et al. 2000, Yeheyis et al. 2010). However, the application of such barriers may become extremely expensive for the lack of suitable clay materials at or near the disposal site, or for high costs of synthetic materials (Cokca and Yilmaz 2004). In such instances, relatively inexpensive material with similar impermeability might be a viable alternative for barrier construction.

Municipal sewage sludge serving as a hydraulic and contaminant barrier might be viable for its low permeability and strong retardation to heavy metal pollutants. Permeability of compacted sewage sludge is as low as clay soils, which could mitigate the heavy metal pollution by reducing the volume of leachate from waste disposal sites (Wang et al. 2010, Zhang et al. 2014). Additionally, sewage sludge generally contains plenty of organic substances, which could strongly adsorb the heavy metals present in the leachate (Rozada et al. 2008). Furthermore, the anaerobic microorganism contained in the sewage sludge could induce a weak alkaline and reduced condition, which might also be helpful to the retardation of heavy metals (Kamon et al. 2002, Wang et al. 2010). Sewage sludge, a waste in an increasing amount from municipal wastewater treatment plant, is a potential source for barrier material construction that might be cost-effective for solid waste landfills and an important step towards sustainability.

In this study, hydraulic conductivity of compacted sewage sludge sample permeated with synthetic heavy metal solution was determined by flexible-wall permeameter, and effluent from each sample was collected and analyzed periodically to 
evaluate the retardation capacity of sewage sludge to heavy metal pollutants. The ultimate goal of this study is to estimate the feasibility of sewage sludge served as a potential source for waste landfill barrier material construction.

\section{Materials and Experimental Methods}

\section{Material \\ Characterization of sewage sludge}

Sewage sludge used in this work was obtained from a municipal wastewater treatment plant in Lanzhou, China. After collection, the sewage sludge was air-dried for 30 days, then ground and passed through 0.5 -mm sieve. Chosen properties of the sewage sludge are listed in Table 1.

Table 1. Properties of sewage sludge used

\begin{tabular}{lr}
\hline \multicolumn{1}{c}{ Properties } & \multicolumn{1}{c}{ Results } \\
\hline Water content & \\
Natural (\%) & 312.84 \\
Air-dried (\%) & 4.00 \\
Liquid limit (\%) & 117.10 \\
Plastic limit (\%) & 54.26 \\
Plasticity index (\%) & 62.84 \\
Specific gravity & 1.85 \\
Ignition loss (\%) & 27.80 \\
Trace element concentration $\left.\mathrm{mg}^{\prime} \mathrm{kg}^{-1}\right)$ & \\
Zinc & 650.00 \\
Cadmium & 2.75 \\
pH(Sewage sludge:distilled water=1:1) & 7.40 \\
\hline
\end{tabular}

Sewage sludge material from the treatment plant had a water content of $312.84 \%$. In this study, water content is defined as the ratio of the weight of water to the dry weight of sewage sludge and is usually expressed as a percentage. Dry weight of sewage sludge was determined at the temperature of $60^{\circ} \mathrm{C}$ instead of the standard drying temperature of $105^{\circ} \mathrm{C}$ to prevent charring of the organic particles. The liquid limit and the plastic limit were measured to be $117.10 \%$ and $54.26 \%$, respectively, using the cone penetrometer method, which was used by O'Kelly in the determination of Atterberg limit of municipal sewage sludge (O'Kelly 2005, O'Kelly 2006). The plastic index, difference between liquid limit and plastic limit, was calculated to be $62.84 \%$. Similar liquid and plastic limits were reported for sewage sludge (Wang et al. 2010). The specific gravity of solids value was 1.85 by using the small pyknometer method. Kerosene was used instead of distilled water as the density fluid in the pyknometer; otherwise the sludge sample would have continued to decompose slowly during the tests (O'Kelly 2005). Ignition of dry powdered test samples at $440^{\circ} \mathrm{C}$ over a period of $18 \mathrm{~h}$ gave a loss on ignition (LOI) value of $27.80 \%$ by dry mass and is a fairly accurate measure of the total organic content (Kalisz et al. 2012, Konen et al. 2002). Trace elements Zn and $\mathrm{Cd}$ in sewage sludge were measured by the following method. About $0.30 \mathrm{~g}$ dry sewage sludge was ground, homogenized and then dissolved in $8 \mathrm{ml} 10 \mathrm{~mol} / \mathrm{HNO}_{3}$ and $5 \mathrm{ml} 20 \mathrm{~mol} / 1$ HF with microwave digestion instrument for $45 \mathrm{~min}$, after that $2 \mathrm{ml} \mathrm{HClO}_{4}$ was added into the digested solution. The solution was heated to dense smoke, then dissolved to clear solution with $\mathrm{HNO}_{3}$ and volume was adjusted to $50 \mathrm{ml}$ for atomic absorption analysis (AAA) of the amount of $\mathrm{Zn}$ and $\mathrm{Cd}$. The $\mathrm{pH}$ of suspension of the sewage sludge mixed with distilled water (solid water ratio 1:1) was 7.40 determined by an electrometric method.

\section{Permeants}

Two synthetic solutions were used as permeants in the hydraulic conductivity tests. Two typical heavy metals, Zn and $\mathrm{Cd}$, were enhanced as target heavy metal pollutants. Power solid $\mathrm{ZnCl}_{2}$ and $\mathrm{CdCl}_{2}$ were added in both permeants. The target doses of $\mathrm{Zn}$ and $\mathrm{Cd}$ were 100 and $150 \mathrm{mg} \cdot \mathrm{L}^{-1}$ in Permeant No. 1, and 300 and $300 \mathrm{mg} \cdot \mathrm{L}^{-1}$ in Permeant No. 2, respectively. Taking in account hydrolysis of both salts, actual doses in the two permeants were strictly determined. Sodium acetate $\left(\mathrm{CH}_{3} \mathrm{COONa}\right)$ and glucose $\left(\mathrm{C}_{6} \mathrm{H}_{12} \mathrm{O}_{6}\right)$ were added as nutrient for growth and reproduction of microorganisms. The concentrations of heavy metal pollutants and nutrient, and other chemical characteristics (pH, Eh, EC) of the permeants are presented in Table 2. Nitrogen gas was bubbled into the permeants for 15 minutes each time before added into the influent pipe to minimize the potential impacts of dissolved oxygen to the redox state within the samples.

Table 2. Chemical characteristics of permeants

\begin{tabular}{lrr}
\hline \multicolumn{1}{c}{ Parameters } & No. 1 & No. 2 \\
\hline $\mathrm{CH}_{3} \mathrm{COONa}\left(\mathrm{mg} \cdot \mathrm{L}^{-1}\right)$ & 3000 & 3000 \\
$\mathrm{C}_{6} \mathrm{H}_{12} \mathrm{O}_{6}\left(\mathrm{mg} \cdot \mathrm{L}^{-1}\right)$ & & 1000 \\
$\mathrm{Zn}^{2+}\left(\mathrm{mg} \cdot \mathrm{L}^{-1}\right)$ & 73.8 & 268.8 \\
$\mathrm{Cd}^{2+}\left(\mathrm{mg} \cdot \mathrm{L}^{-1}\right)$ & 100.0 & 277.9 \\
$\mathrm{Eh}(\mathrm{mV})$ & 218 & 225 \\
$\mathrm{pH}$ & 5.36 & 5.19 \\
$\mathrm{EC}\left(\mathrm{mS} \cdot \mathrm{cm}^{-1}\right)$ & 1.83 & 1.93 \\
\hline
\end{tabular}

Note: a dash means no addition.

\section{Experimental Methods}

\section{Compaction test and sample preparation}

A standard Proctor compaction test, from which the maximum dry density and optimum water content could be determined, was conducted on air-dried sludge with distilled water as pore liquid followed by ASTM D 698 to evaluate the compaction characteristics. Distilled water was added to the air-dried sewage sludge to obtain the desired water content of $62 \%$, which was $2 \%$ above optimum water content determined from the compaction tests. Then the mixture was covered with a plastic bag and allowed to equilibrate overnight. The hydrated mixture was then compacted to triplicate cylinder samples ( $\mathrm{S} 1$, S2, S3) using standard Proctor compactive effort $\left(600 \mathrm{KJ} \cdot \mathrm{m}^{-3}\right)$. Afterwards, the samples were trimmed to a specific dimension (102 $\mathrm{mm}$ in diameter and $30 \mathrm{~mm}$ in height). Diameter, height and mass of each sample were measured and recorded. Subsequently, the samples were placed between filter papers and porous stones and then enclosed in rubber membrane and sealed with O-rings before being set on the pedestals of the flexible-wall permeameter. 


\section{Hydraulic conductivity measurement}

Hydraulic conductivity tests were performed on the samples using a flexible-wall permeameter (HM-4160A, Humboldt) followed by the falling head method of ASTM D5084. Fig. 1 shows the sketch of flexible-wall permeameter used in the tests. The flexible-wall permeameter generally has the advantages of applying saturation backpressure and diminishing side wall leakage, which means short testing time and precise test results for low hydraulic conductivity materials.

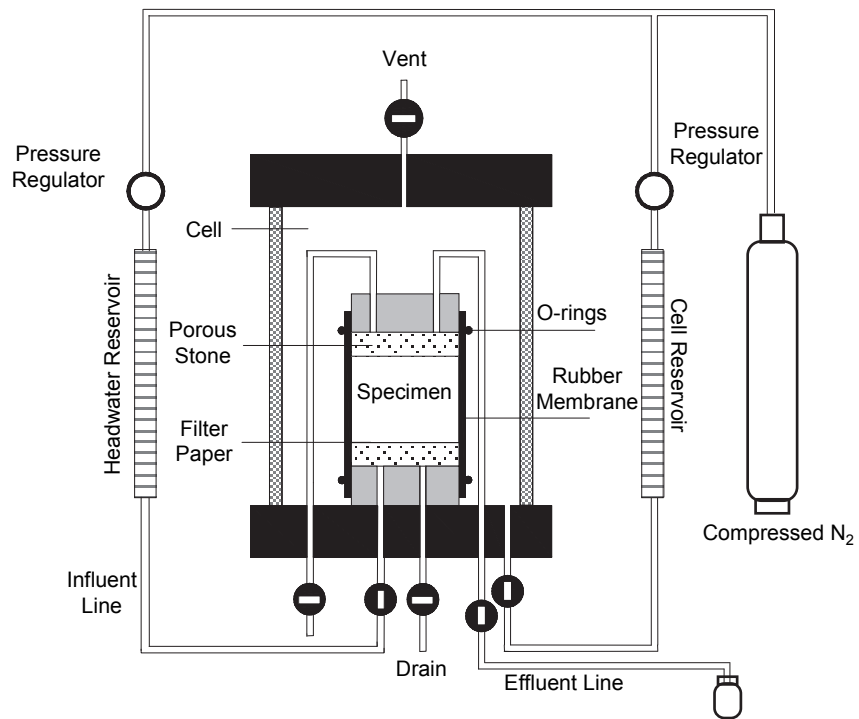

Fig. 1. Schematic diagram of flexible-wall permeameter

The three samples, S1, S2 and S3, were first saturated with distilled water and then permeated with the two permeants mentioned above in sequence under three different effective stresses, $100 \mathrm{kPa}, 200 \mathrm{kPa}$ and $300 \mathrm{kPa}$, respectively. The three levels of effective stress were designed corresponding to different overburden loads induced by the variation height of solid waste. Fig. 2 shows the gas pressures on the gas-water interface both in the headwater reservoir and in the cell reservoir during the tests. In this study, back pressure and influent pressure are the sum of gas pressure applied on the gas-water interface and hydraulic head in the headwater reservoir, and confining pressure is the sum of gas pressure applied on the gas-water interface and hydraulic head in the cell reservoir. In fact, difference of hydraulic head in the reservoir could be neglected in comparison with the difference of gas pressure on the gas-water interface. Effective stress (confining pressure minus backpressure or influent pressure) for each sample was maintained at a specific level allthrough the tests by persistent monitoring and adjustment of gas pressure in the reservoirs. All the pressures were provided by compressed nitrogen gas to diminish potential influence to the redox state of the samples. Back pressures were applied to the samples level by level until B value (pore-pressure coefficient) exceeded 0.95 , which is an indication of adequate saturation of samples. Then the samples were permeated with the two mentioned permeants, Permeant No. 1 for 20 days initially and then switched to Permeant No. 2. The test was terminated when hydraulic conductivities of all samples were stable after 50 days of permeation. Hydraulic head and gas pressure on gas-water interface, both in the headwater reservoir and in the cell reservoir, as well as the surrounding temperature, were recorded for the calculation and correction of hydraulic conductivity.

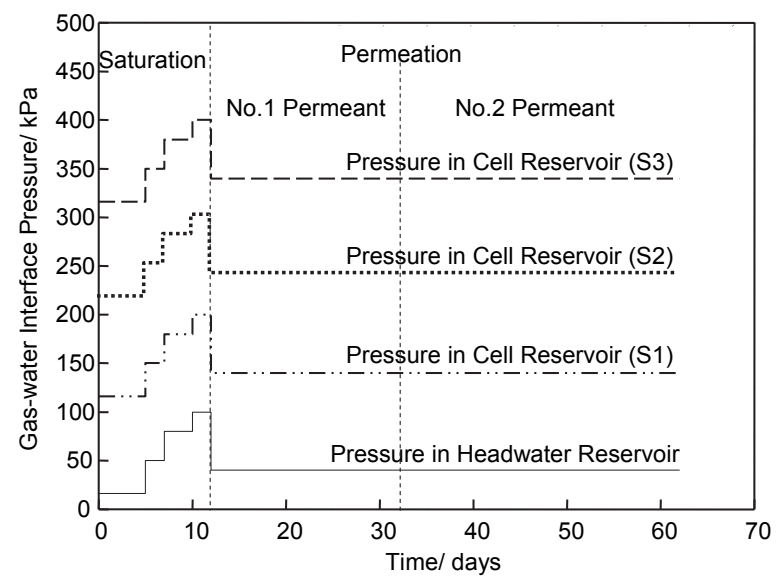

Fig. 2. Gas pressure on the gas-water interface in the reservoirs during the tests

Hydraulic conductivity of sewage sludge sample was calculated following the Darcy's Law and corrected to the standard temperature $\left(20^{\circ} \mathrm{C}\right)$ using the following equation (1) and equation (2), respectively:

$$
k=\frac{a L}{A\left(t_{2}-t_{1}\right)} \ln \left(\frac{\Delta h_{1}}{\Delta h_{2}}\right)
$$

where $k$ is hydraulic conductivity $(\mathrm{cm} / \mathrm{s}) ; a$ is cross-sectional area of the headwater reservoir $\left(\mathrm{cm}^{2}\right) ; A$ is cross-sectional area of the sample $\left(\mathrm{cm}^{2}\right) ; t_{1}$ and $t_{2}$ are time at start and end of the permeation trial, respectively (s); $\Delta h_{1}$ and $\Delta h_{2}$ are head loss (influent pressure minus effluent pressure) across the sample at $t_{1}$ and $t_{2}$, respectively $(\mathrm{cm})$. In this study, no effluent pressure was applied in order to facilitate the collection and analysis of effluent timely and thus head loss was equal to the influent pressure.

$$
k_{20}=R_{T} k
$$

with

$$
R_{T}=2.2902\left(0.9842^{T}\right) / T^{0.1702}
$$

where $k_{20}$ is hydraulic conductivity corrected to $20^{\circ} \mathrm{C}(\mathrm{cm} / \mathrm{s})$; $R_{\mathrm{T}}$ is ratio of the viscosity of water at test temperature to the viscosity of water at $20^{\circ} \mathrm{C} ; T$ is average test temperature during the permeation $\operatorname{trial}\left({ }^{\circ} \mathrm{C}\right)$.

\section{Effluent collection and analysis}

An effluent from each sample during permeation was collected with a polyethylene bag periodically. The collected effluents were analyzed for $\mathrm{pH}$, redox potential (Eh), electrical 
conductivity (EC) and heavy metals. $\mathrm{pH}$, redox potential (Eh) and electrical conductivity (EC) were measured immediately after collection. Then the effluent was filtered through a $0.45-\mu \mathrm{m}$ syringe filter for analysis of heavy metal using atomic absorption spectrophotometer (AAS) (Hitachi 180-80).

\section{Results and discussion}

\section{Compaction test}

Variations of bulk density and dry density versus water content of air-dried sewage sludge are plotted in Fig. 3. The compacted densities were low in comparison with mineral soils, but in accordance with the low specific gravity of sewage sludge. The dry density-water content was comparatively flat, similar results of compaction tests of sewage sludge were also reported (Stone et al. 1998, O'Kelly 2005, O'Kelly 2006). The maximum dry density of $0.79 \mathrm{~g} \cdot \mathrm{cm}^{-3}$ was achieved when water content was at about $60 \%$, the optimum water content for compaction. Maximum dry density and optimum water content of sewage sludge from several wastewater treatment plants are summarized in Table 3. Differences of maximum dry density and optimum water content among the various sewage sludges might be partly attributed to the variation of ignition loss, an indication of organic matter content. As the most likely composition of organic matter, organic macromolecules and bacteria in the sewage sludge contain bound water, which is an important part of water within sewage sludge and hard to be removed under mechanical means (O'Kelly 2006). Thus, increase in organic matter content usually results in the increase in optimum water content and decrease in maximum dry density of sewage sludge.

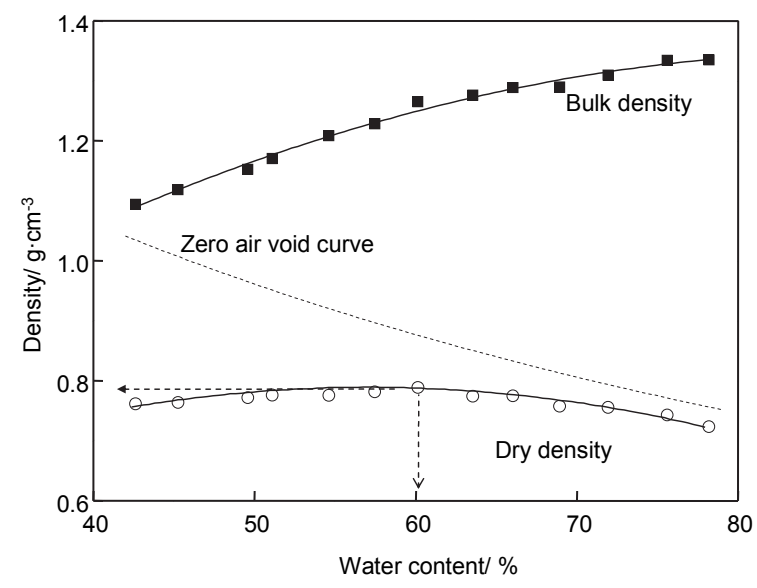

Fig. 3. Compacted density versus water content

\section{Hydraulic conductivity}

The results of hydraulic conductivity tests on the three samples permeated with two permeants are presented in Fig. 4. The hydraulic conductivity of S1 was about $2.6 \times 10^{-8} \mathrm{~cm} \cdot \mathrm{s}^{-1}$ initially and decreased steadily and eventually stabilized to an average value of $1.3 \times 10^{-8} \mathrm{~cm} \cdot \mathrm{s}^{-1}$ at the end of the permeation. Similar trend for the hydraulic conductivity of S2 and S3 can be seen from Fig. 4. In general, hydraulic conductivity of each sample decreased to about half of the initial value during permeation.

Particular consolidation properties of sewage sludge might be one reason for the decrease of the hydraulic conductivity. O'Kelly evaluated consolidation properties of municipal sewage sludge and found that secondary compression induced by creep deformation and biodegradation of the solid organic particles was progressively difficult and dominant in consolidation of sewage sludge when water content was below about 650\% (O'Kelly 2006). Void ratio, an indirect indication of hydraulic conductivity, might be decreased persistently under effective stress applied throughout the tests.

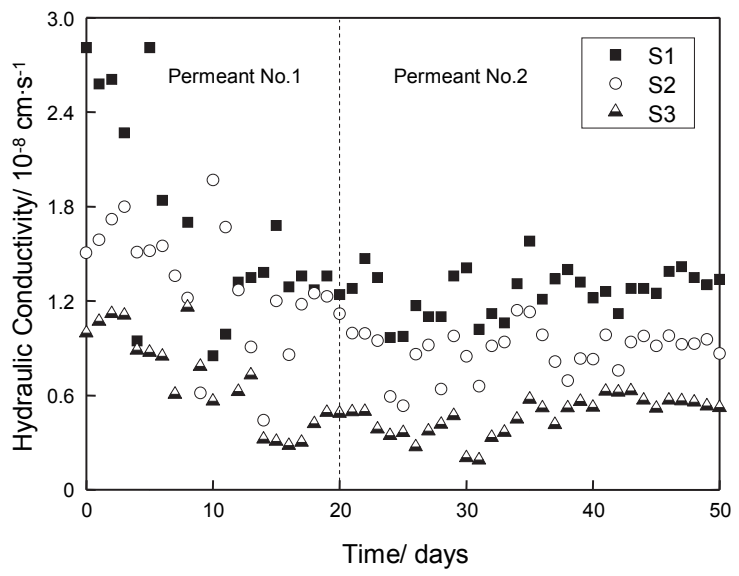

Fig. 4. Hydraulic conductivity of three samples versus time

It was well known that the activities of microorganisms would lead to diminishing of pore volume and thus reduction of hydraulic conductivity of soils. Biological clogging caused by the formation of inorganic precipitation and biofilm on the surface of solid particles due to the growth and reproduction of anaerobic microorganisms was an important mechanism of pore clogging (Francisca and Glatstein 2010). Anaerobic state was maintained in each sample by the maximum restriction of oxygen in influent bubbled with nitrogen gas and compressed nitrogen gas served as pressure resources. Enhanced activities

Table 3. Maximum dry density and optimum water content of several sewage sludges

\begin{tabular}{lcccc}
\hline $\begin{array}{c}\text { Location } \\
\text { of sewage sludge }\end{array}$ & $\begin{array}{c}\text { Ignition loss } \\
(\%)\end{array}$ & $\begin{array}{c}\text { Optimum water content } \\
(\%)\end{array}$ & $\begin{array}{c}\text { Maximum dry density } \\
\left(\mathrm{g} \cdot \mathrm{cm}^{-3}\right)\end{array}$ & Source \\
\hline Tullapore & 70.0 & 90 & 0.56 & O'Kelly 2005 \\
Valencia & 67.2 & 88 & 0.54 & Stone et al. 1998 \\
San Fernando & 49.1 & 79 & 0.68 & Stone et al. 1998 \\
Trincity & 33.1 & 75 & 0.72 & Stone et al. 1998 \\
Lanzhou & 27.8 & 60 & 0.79 & This study \\
Santa Cruz & 14.3 & 34 & 1.25 & Stone et al. 1998 \\
\hline
\end{tabular}


of anaerobic microorganisms may be an important cause of decrease of hydraulic conductivity under this condition.

Hydraulic conductivities of the samples may be influenced by variation of diffuse double layer of clay particles induced by alternation of pore fluid during the tests. The distance between surface of negatively charged clay particle and center of gravity of diffuse double layer $1 / \kappa$ may be related to the thickness of the double layer (Mitchell 1993). For an electrolyte containing various ions, $\kappa$ is given as follows (Hunter 1993):

$$
\kappa^{2}=\frac{e^{2} \sum n_{i}^{o} z_{i}^{2}}{\varepsilon k T}
$$

where $e$ is the charge of the electron $\left(1.60 \times 10^{-19} \mathrm{C}\right)$; same in the equation (4) is the numbers of ions of type $i$ in the solution per cubic meter; $z_{\mathrm{i}}$ is the valence of ion $i ; k$ is Boltzmann's constant $\left(1.38 \times 10^{-19} \mathrm{~J} \cdot \mathrm{K}^{-1}\right) ; \varepsilon$ is the permittivity of solution $\left(\mathrm{C}^{2} \cdot \mathrm{J}^{-1} \cdot \mathrm{m}^{-1}\right)$ and $T$ is absolute temperature $(\mathrm{K})$.

It was reported that $\kappa$ is related to ion strength of effluent in the following equation (Kashir and Yanful 2001):

$$
\kappa=3.28 \sqrt{I}\left(\mathrm{~nm}^{-1}\right)
$$

Griffin and Jurinak (1973) summarized a linear fitting relationship whose correlation coefficient was 0.996 between ion strength and electrical conductivity as follows:

$$
I=0.013 E C
$$

where $I$ is ion strength $\left(\mathrm{mol} \cdot \mathrm{L}^{-1}\right)$ and EC is electrical conductivity $\left(\mathrm{mmhos} \cdot \mathrm{cm}^{-1}\right)$.

An inverse relationship between thickness of double diffusive layer $(1 / \kappa)$ of clay particles and electrical conductivity (EC) of effluent could be obtained from the combination of equation (5) and equation (6). Variation of electrical conductivity of the effluent versus time is illustrated in Fig. 5. It could be seen from Fig. 5 that electrical conductivities of effluent from all samples were nearly the same during the tests. Electrical conductivity of effluent increased in the first 10 days and decreased steadily from the 10th day to the 37 th day and then increased slightly thereafter. The variation of electrical conductivity of effluent might be attributed to the combination of flushing of dissolved salts and retardation of heavy metal ions within the samples. On the whole, electrical conductivity of effluent of all samples decreased with the proceeding of the permeation. Therefore, decrease of hydraulic conductivity of the samples might be attributed to the increase in the thickness of double layer and the following reduction of pore volume.

Another phenomenon indicated in Fig. 4 is variation of hydraulic conductivity among the three samples under different effective stresses. Hydraulic conductivity of sample is smaller under higher effective stress, which is in accordance with traditional theory about permeability of mineral soils. Hydraulic conductivity of the three compacted sewage sludge is in the orders of $10^{-8}$ to $10^{-9} \mathrm{~cm} \cdot \mathrm{s}^{-1}$, which is far less than the recommended hydraulic conductivity $\left(1 \times 10^{-7} \mathrm{~cm} \cdot \mathrm{s}^{-1}\right)$ for barrier materials. Based on the results of this study, it could be concluded that municipal sewage sludge may be a suitable material of barriers constructed for the containment of pollution sources.

\section{Effluent Chemistry Analysis}

Neither $\mathrm{Zn}$ nor Cd above the detection limits $\left(0.02 \mathrm{mg} \cdot \mathrm{L}^{-1}\right)$ was detected in the effluent of the three samples all through the permeation tests. The test results indicated the strong ability of sewage sludge in the retardation of heavy metal ions.

Effluent $\mathrm{pH}$ versus time during the tests is displayed in Fig. 6. Increase in $\mathrm{pH}$ of effluent from the three samples was obvious in comparison with both influents. This increase might be attributed to the anaerobic fermentation of the organic matter in sewage sludge and the dissolution of aluminosilicate minerals (Sridharan et al. 2001). Variation of effluent $\mathrm{pH}$ between 7.2 and 8.2 is an indirect indication of $\mathrm{pH}$ of pore fluid in the sewage sludge samples. Under the neutral to weak alkaline conditions in the sewage sludge, heavy metal ions would precipitated as insoluble hydroxides and carbonates, which might be an important retardation mechanism of heavy metal.

As mentioned before, great efforts were made to restrict oxygen into the samples. Therefore, dissolved oxygen in the permeants and samples would be consumed at a greater rate than provided. This leads to a reduced condition that can be

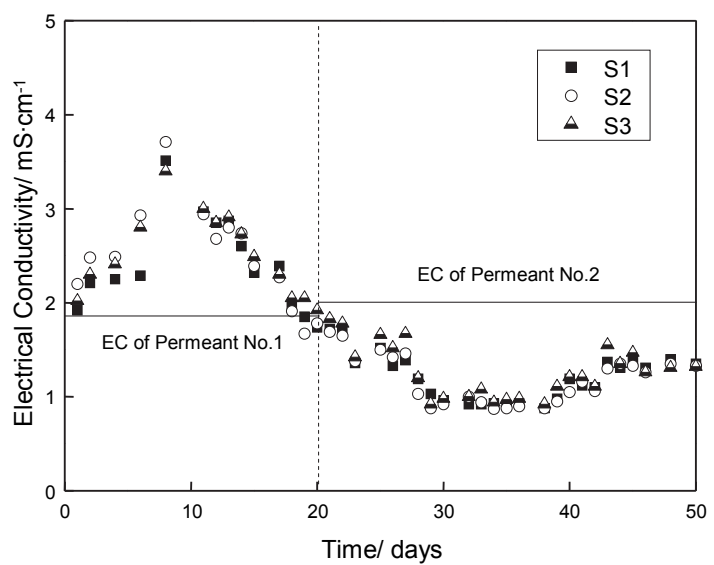

Fig. 5. Electrical conductivity (EC) of effluent versus time

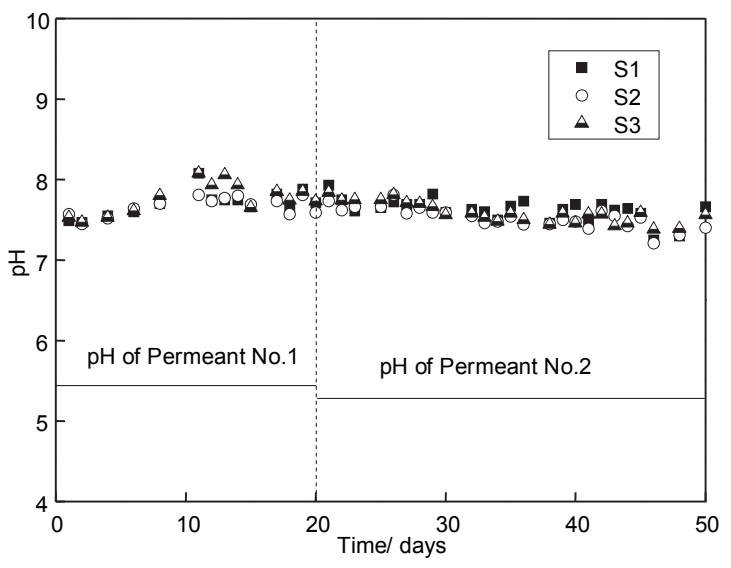

Fig. 6. Effluent $\mathrm{pH}$ versus time 


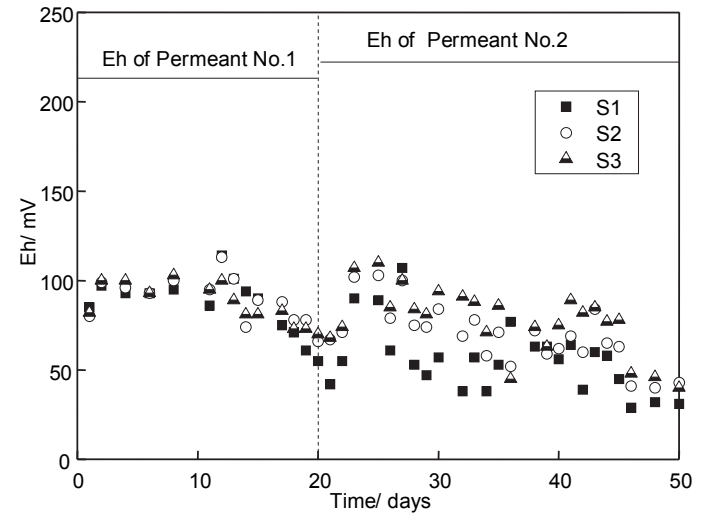

Fig. 7. Effluent Eh versus time

confirmed by the decreased redox potential of effluent shown in Fig. 7. In fact, redox potential within the samples would be lower than that displayed in Fig. 7 due to the partial oxidation of effluent to some extent. For the low permeability of sewage samples, a long time was usually needed to collect sufficient effluent for various determinations, such as Eh, EC, $\mathrm{pH}$ and heavy metal ions analysis. Hence, exposure of effluent to oxygen is hard to avoid. Anaerobic reduced conditions within the samples induced by the fast consumption of oxygen by the respiration of microorganisms might be contributed to the retardation of heavy metal (Kamon et al. 2002).

Heavy metals could also be retarded by the adsorption of sewage sludge in many approaches, such as biosorption, complexing and ion exchange (Mohan and Gandhimathi 2009). Batch adsorption tests were conducted on the sewage sludge used in this study (Zhang et al. 2010) and the results evaluated by the Langmuir adsorption equation showed that the maximum adsorption capacities of $\mathrm{Zn}^{2+}$ and $\mathrm{Cd}^{2+}$ of the sewage sludge were $13.62 \mathrm{mg} \cdot \mathrm{g}^{-1}$ and $15.60 \mathrm{mg} \cdot \mathrm{g}^{-1}$, respectively (Fig. 8). Similar results were also reported (Solari et al. 1996, Lister and Line 2001).

\section{Conclusions}

Laboratory experiments were performed to investigate the compaction characteristics, hydraulic conductivity and retardation mechanism of municipal sewage sludge. The following conclusions could be drawn from this study:

1. Bulk density and dry density of sewage sludge were low in comparison with mineral soils but in line with its low specific gravity. The maximum dry density of $0.79 \mathrm{~g} \cdot \mathrm{cm}^{-3}$ was achieved at the optimum water content of $60 \%$.

2. Decrease in hydraulic conductivity of compacted sewage sludge was the result of combined action of secondary compression, biological clogging and thickness increase in double layer. With a low hydraulic conductivity in the orders of $10^{-8}$ to $10^{-9} \mathrm{~cm} \cdot \mathrm{s}^{-1}$, sewage sludge might serve as a potential source for waste landfill barrier material construction.

3. Retardation of compacted sewage sludge to heavy metal should be attributed to the anaerobic reduced neutral to weak alkaline conditions induced by the respiration of microorganisms.

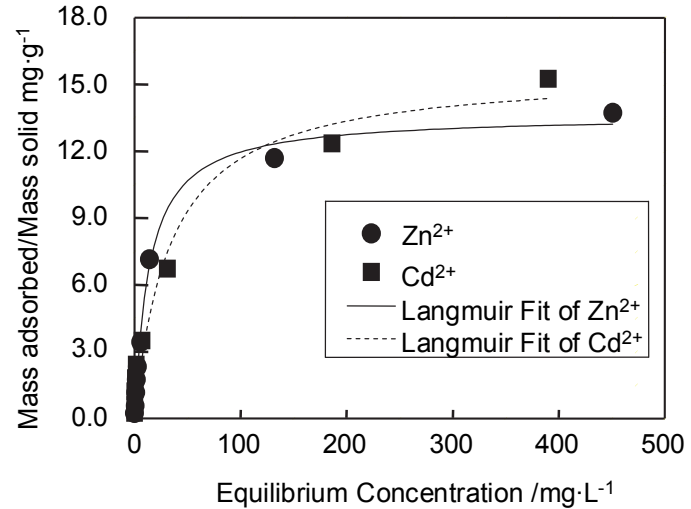

Fig. 8. Langmuir Isotherms of $\mathrm{Zn}^{2+}$ and $\mathrm{Cd}^{2+}$ on sewage sludge

\section{Acknowledgments}

The work described in this paper was sponsored by the Research Fund for the Doctoral Program of Higher Education of China (Grant No. 20110211110025).

\section{References}

Baun, D.L. \& Christensen, T.H. (2004). Speciation of heavy metals in landfill leachate: a review, Waste management \& research, 22, 1, pp. 3-23.

Ciesielczuk, T., Rosik-Dulewska, C. \& Kochanowska, K. (2014). The influence of biomass ash on the migration of heavy metals in the flooded soil profile-model experiment. Archives of Environmental Protection, 40, 4. pp. 3-15.

Cokca, E. \& Yilmaz, Z. (2004). Use of rubber and bentonite added fly ash as a liner material. Waste management, 24, 2, pp. 153-164.

Duruibe, J.O., Ogwuegbu, M.O.C. \& Egwurugwu, J.N. (2007). Heavy metal pollution and human biotoxic effects. International Journal of Physical Sciences, 2, 5, pp. 112-118.

Francisca, F.M. \& Glatstein, D.A. (2010). Long term hydraulic conductivity of compacted soils permeated with landfill leachate. Applied Clay Science, 49, 3, pp. 187-193.

Griffin, R.A. \& Jurinak, J.J. (1973). Test of a new model for the kinetics of adsorption-desorption processes. Soil Science Society of America Journal, 37, 6, pp. 869-872.

Hunter, R.J. (1993). Introduction to modern colloid science, Oxford University Press, Oxford 1993.

Järup, L. (2003). Hazards of heavy metal contamination. British Medical Bulletin, 68, 1, pp. 167-182.

Jonczak, J. \& Parzych, A. (2014). The content of heavy metals in the soil and litterfall an a beech-pine-spruce stand in northern Poland. Archives of Environmental Protection, 40, 4, pp. 67-77.

Jung, C.H., Matsuto, T., Tanaka, N. \& Okada, T. (2004). Metal distribution in incineration residues of municipal solid waste (MSW) in Japan. Waste Management, 24, 4, pp. 381-391.

Kalisz, B., Lachacz, A., Glazewski, R. \& Klasa, A. (2012). Effect of Municipal Sewage Sludge under Salix Plantations on Dissolved Soil Organic Carbon Pools. Archives of Environmental Protection, 38, 4, pp. 87-97.

Kamon, M., Zhang, H. \& Katsumi, T. (2002). Redox effects on heavy metal attenuation in landfill clay liner. Soils and Foundations, 42, 3, pp. 115-126.

Kashir, M. \& Yanful, E.K. (2001). Hydraulic conductivity of bentonite permeated with acid mine drainage. Canadian Geotechnical Journal, 38, 5, pp. 1034-1048. 
Konen, M.E., Jacobs, P.M., Burras, C.L., Talaga, B.J. \& Mason, J.A. (2002). Equations for predicting soil organic carbon using loss-on-ignition for north central US soils. Soil Science Society of America Journal, 66, 6, pp. 1878-1881.

Lemanowicz, J. \& Bartkowiak, A. (2013). Diagnosis of the content of selected heavy metals in the soils of the Pałuki region against their enzymatic activity. Archives of Environmental Protection, 39, 3, pp. 23-32.

Lister, S.K. \& Line, M.A. (2001). Potential utilisation of sewage sludge and paper mill waste for biosorption of metals from polluted waterways. Bioresource Technology, 79, 1, pp. 35-39.

Lottermoser, B. (2010). Mine wastes: characterization, treatment and environmental impacts, Springer Science \& Business Media, Berlin 2010

Manassero, M., Benson, C.H. \& Bouazza, A. (2000). Solid waste containment systems, in: ISRM International Symposium, International Society for Rock Mechanics(Eds.). The Chemical Rubber Company Press, Boca Raton 2000.

Mitchell, J.K. (1993). Fundamentals of soil behavior, Wiley, New York 1993

Mohan, S. \& Gandhimathi, R. (2009). Removal of heavy metal ions from municipal solid waste leachate using coal fly ash as an adsorbent. Journal of Hazardous Materials, 169, 1, pp. 351-359.

O'Kelly, B.C. (2005). Consolidation properties of a dewatered municipal sewage sludge. Canadian Geotechnical Journal, 42, 5, pp. 1350-1358.

O'Kelly, B.C. (2006). Geotechnical properties of municipal sewage sludge. Geotechnical \& Geological Engineering, 24, 4, pp. 833-850.
Rozada, F., Otero, M., Morán, A. \& García, A. I. (2008). Adsorption of heavy metals onto sewage sludge-derived materials. Bioresource Technology, 99, 14, pp. 6332-6338.

Solari, P., Zouboulis, A.I., Matis, K.A. \& Stalidis, G.A. (1996). Removal of toxic metals by biosorption onto nonliving sewage sludge. Separation science and technology, 31, 8, pp. 1075-1092.

Sridharan, A., Rajasekhar, C. \& Pandian, N. S. (2001). Heavy metal retention behavior of clayey soils. Journal of testing and evaluation, 29, 4, pp. 361-371.

Stone, R.J., Ekwue, E.I. \& Clarke, R.O. (1998). Engineering properties of sewage sludge in Trinidad. Journal of agricultural engineering research, 70, 2, pp. 221-230.

Wang, B., Zhang, H., Fan, Z. \& Ju, Y. (2010). Compacted sewage sludge as a barrier for tailing impoundment. Environmental Earth Sciences, 61, 5, pp. 931-937.

Yeheyis, M.B., Shang, J.Q. \& Yanful, E.K. (2009). Feasibility of using coal fly ash for mine waste containment. Journal of environmental engineering, 136, 7, pp. 682-690.

Zhang, H., Wang, B., Dong, X. , Fan, Z. \& Ju, Y. (2010). Feasibility of sewage sludge used as filling material in permeable reactive barrier, Environmental Science, 31, 5, pp. 1280-1286. (in Chinese)

Zhang, H., Zhang, Q., Yang, B. \& Wang, J. (2014). Compacted sewage sludge as a barrier for tailings: the heavy metal speciation and total organic carbon content in the compacted sludge specimen, PLoS ONE, 9, 6, e100932. doi. 10.1371/journal.pone.0100932. 